\title{
Growth and Quality Parameters of Popcorn (Zea mays var. Everta) as Influenced by Application of Potassium and Sulphur Levels
}

\author{
Pamu Swetha*, S.G. Savalia, Shalini Kumari and Dharmik Solanki \\ Department of Agricultural Chemistry and Soil Science, College of Agriculture, \\ Junagadh Agricultural University, Junagadh - 362 001, Gujarat, India \\ *Corresponding author
}

\section{A B S T R A C T}

Keywords

Rabi popcorn, Potassium levels, Sulphur levels, Growth parameters, Quality parameters.

Article Info

Accepted: 04 June 2017 Available Online: 10 August 2017
A field experiment was conducted during 2013-14 rabi season, at the Instructional Farm, College of Agriculture, Junagadh Agricultural University, Junagadh to asses response of popcorn (Zea mays L. everta Sturt) to four levels each of potassium viz., 0, 30, 60 and $90 \mathrm{~kg} \mathrm{~K}_{2} \mathrm{O} \mathrm{ha}^{-1}$ and sulphur viz., $0,20,40,60 \mathrm{~kg} \mathrm{~S} \mathrm{ha}^{-1}$. The results of different potassium and sulphur levels depicted that application of potassium @ $60 \mathrm{~kg} \mathrm{~K}_{2} \mathrm{O} \mathrm{ha}^{-1}$ as well as sulphur@ $@ 40 \mathrm{~kg} \mathrm{~S}^{-1}$ significantly increased the plant height, stem thickness, number of leaves per plant and crude protein content in seed.

\section{Introduction}

Maize is one of the most important cereal crop next to rice, wheat and jowar in respect of area and production in India. According to the character of the kernels, it is classified in various groups among which "popcorn" is major one. Popcorn (Zea mays L. var. everta Sturt) also known as popping corn. Popcorn is popular and nutritious snack food in many parts of World. All parts of corn such as grain, branches and leaves, even corn cob and corn silk is used numerously in human nutrition, fed livestock and poultry and pharmaceutical industry. Potassium and sulphur play a vital role in the nutrition of plants. Fertility analysis of Indian soils has indicated that the soils are deficient in sulphur and medium to low in the potash. In fact, these nutrients are lacking mostly in the soils of Saurashtra region. Therefore, application of chemical fertilizers becomes essential to raise the crop yield. Potassium is an essential element for plant growth and development and is the most abundant cation in plants, making up 3-5\% of a plant's total dry weight. Sulphur plays an important role in enhancing the productivity of pop corn crop.

\section{Materials and Methods}

The experiment was conducted during rabi season 2013-14 in D-5 plot of Instructional Farm at Krushigadh, College of Agriculture, Junagadh Agricultural University, Junagadh. It is Geographically Junagadh is situated at 
$21.5^{0} \mathrm{~N}$ latitude and $70.5^{\circ} \mathrm{E}$ longitude with an altitude of $60 \mathrm{~m}$ above the mean sea level. The experiments were laid out in Factorial Randomized Block Design having 16 treatments with three replications. The gross and net plot sizes were $5.0 \mathrm{~m} \mathrm{X} 3.6 \mathrm{~m}$ and 4 m X $2.40 \mathrm{~m}$, respectively. The experiment consisted of 4 levels of potassium $(0,30,60$ and $\left.90 \mathrm{~kg} \mathrm{~K}_{2} \mathrm{O} \mathrm{ha}^{-1}\right)$ and4 levels of sulphur ( 0 , 20, 40, $60 \mathrm{~kg} \mathrm{~S} \mathrm{ha}^{-1}$ ).

The soil of the experimental field was medium black calcareous soil with $\mathrm{pH} 7.9$ and EC $0.35 \mathrm{dS} \mathrm{m}^{-1}$. The crop was fertilized with potassium and sulphur as per treatment allotted to each plot in the form of MOP and Cosavet fertis. WG. (90\%) in basal application and nitrogen and phosphorus in the form of urea, diammonium phosphate in the furrows, respectively $1 / 3^{\text {rd }}$ nitrogen applied before sowing, $1 / 3^{\text {rd }}$ at 20 days after sowing and remaining $1 / 3^{\text {rd }}$ at 40 days after sowing, and phosphorus applied as basal. Amber popcorn variety was used as planting material in this study.

The seeds were dibbled at a spacing of $60 \mathrm{~cm}$ x $20 \mathrm{~cm}$ using a seed rate of $15 \mathrm{~kg} \mathrm{ha}^{-1}$ during the last week of November.

Five plants were selected at random from each plot to record individual plant growth parameters like plant height, stem thickness, number of leaves per plant, 50\% silking, 50\% tasseling by using standard procedure. All other recommended agronomic practices and plant protection measures were carried out to all treatments uniformly during the course of study.

\section{Results and Discussion}

\section{Effect of potassium}

\section{Growth parameters}

Statistical analysis of the data (Table 1 and Fig. 1) revealed that among the different levels of potassium, the $\mathrm{K}_{3}\left(60 \mathrm{~kg} \mathrm{~K}_{2} \mathrm{O} \mathrm{ha}{ }^{-1}\right)$ as level was recorded significantly the higher plant height at 60 DAS $(150.92 \mathrm{~cm})$ and at harvest $(197.91 \mathrm{~cm})$, which was found statistically at par with $90 \mathrm{~kg} \mathrm{~K}_{2} \mathrm{O} \mathrm{ha}^{-1}\left(\mathrm{~K}_{4}\right)$ at 60 DAS $(144.97 \mathrm{~cm})$.

The lowest plant height was observed under $\mathrm{K}_{1}$ (control), while it did not exert their significant influence on plant height at 30 DAS.

The application of $60 \mathrm{~kg} \mathrm{~K}_{2} \mathrm{O} \mathrm{ha}^{-1}\left(\mathrm{~K}_{3}\right)$ and 90 $\mathrm{kg} \mathrm{K}_{2} \mathrm{O} \mathrm{ha}^{-1}\left(\mathrm{~K}_{4}\right)$ remained comparable and recorded significantly the higher stem diameter (Table 1 and Fig. 2) of $2.03 \mathrm{~cm}$ and $2.36 \mathrm{~cm}$, respectively at 60DAS and harvest, whereas at harvest, it was also at par with 30 $\mathrm{kg} \mathrm{K}_{2} \mathrm{O} \mathrm{ha}^{-1}\left(\mathrm{~K}_{2}\right)$ and $90 \mathrm{~kg} \mathrm{~K}_{2} \mathrm{O} \mathrm{ha}^{-1}\left(\mathrm{~K}_{4}\right)$ with the value of $2.29 \mathrm{~cm}$ and $2.34 \mathrm{~cm}$, respectively, while it exhibited their nonsignificant influence on stem diameter at 30 DAS.

The application of $60 \mathrm{~kg} \mathrm{~K} \mathrm{~K}_{2} \mathrm{O} \mathrm{ha}^{-1}\left(\mathrm{~K}_{3}\right)$ recorded significantly higher number of leaves per plant (14), whereas potassium exerted their non-significant influence on number of leaves per plant at 30 and 60 DAS (Table 1 and Fig. 3).

The perusal of data (Table 1) observed that these potassium levels were unable to exert their significant influence on days to 50\% silking, days to $50 \%$ tasseling or leaf stem ratio.

Potassium is known to augment cell division and cell expansion resulting in increasing in positive effect on growth parameter like plant height, stem thickness and number of leaves per plant.

The similar findings were recorded by Ahmed et al., (1992), Kalpana and Krishnarajan (2002), Maurya et al., (2004) and Brar et al., (2012). 


\section{Effect of sulphur}

\section{Growth parameters}

Statistical analysis of the data (Table 1 and Fig. 1) revealed that among the different levels of sulphur, the $S_{3}\left(40 \mathrm{~kg} \mathrm{~S} h a^{-1}\right)$ level was registered significantly the higher plant height at 60 DAS $(151.13 \mathrm{~cm})$ and at harvest $(197.96 \mathrm{~cm})$, which was found statistically at par with $60 \mathrm{~kg} \mathrm{~S} \mathrm{ha}^{-1}\left(\mathrm{~S}_{4}\right)$ at 60 DAS $(146.25 \mathrm{~cm})$ and with $20 \mathrm{~kg} \mathrm{~S} \mathrm{ha}^{-1}\left(\mathrm{~S}_{2}\right)$ and 60 $\mathrm{kg} \mathrm{S} \mathrm{ha}{ }^{-1}\left(\mathrm{~S}_{4}\right)$ at harvest with the value of $192.18 \mathrm{~cm}$ and $194.18 \mathrm{~cm}$, respectively.

The lowest plant height was observed under $\mathrm{S}_{1}$ (control), while different levels of potassium and sulphur did not exert their significant influence on plant height at 30 DAS.

The application of $40 \mathrm{~kg} \mathrm{~S} h a^{-1}\left(\mathrm{~S}_{3}\right)$ recorded significantly the maximum stem diameter at 60 DAS $(2.01 \mathrm{~cm})$ and at harvest $(2.33 \mathrm{~cm})$, which were found significantly at par with 60 $\mathrm{kg} \mathrm{S} \mathrm{ha}{ }^{-1}\left(\mathrm{~S}_{4}\right)$ at 60 DAS with the value of $1.89 \mathrm{~cm}$, whereas at harvest, it was at par with $\mathrm{S}_{2}\left(20 \mathrm{~kg} \mathrm{Sha}^{-1}\right)$ and $\mathrm{S}_{4}\left(60 \mathrm{~kg} \mathrm{Sha}^{-1}\right)$ with the value of $2.23 \mathrm{~cm}$ and $2.28 \mathrm{~cm}$, respectively, while it did not executed their significant influence on stem diameter at 30 DAS (Table 1 and Fig. 2).

Application of $40 \mathrm{~kg} \mathrm{~S} \mathrm{ha}^{-1}\left(\mathrm{~S}_{3}\right)$ recorded significantly higher number of leaves per plant (12.89). Sulphur manifested their nonsignificant influence on number of leaves per plant at 30 and 60 DAS (Table 1 and Fig. 3).

The perusal of data (Table 1) observed that these sulphur levels were unable to exert their significant influence on days to $50 \%$ silking, days to $50 \%$ tasseling or leaf stem ratio.

The increase in growth parameters might be due to the beneficial effect of sulphur on the various metabolic activities and also because of its important role in cell division, photosynthetic process and formation of chlorophyll in the leaf and also increases the plant height, stem thickness and number of leaves per plant were also observed by Bhatt and Jain (2012), Aslam et al., (2013), Dechassa et al., (2013).

\section{Interaction effect}

The interaction effect of potassium and sulphur levels on plant height, stem thickness, number of leaves per plant, days to $50 \%$ silking and days to $50 \%$ tasseling at 30,60 DAS and at harvest was found non-significant

\section{Quality parameters}

\section{Crude protein content in seed}

\section{Effect of potassium}

An assessment of data (Table 1) revealed that by application of $60 \mathrm{~kg} \quad \mathrm{~K}_{2} \mathrm{O} \quad \mathrm{ha}^{-1}\left(\mathrm{~K}_{3}\right)$ potassium recorded significantly the higher crude protein content of cob (12.07\%), whereas, the lowest crude protein content in seed $(10.68 \%)$ was recorded under $\mathrm{K}_{1}$ (control) and potassium did not imparted their significant influence on moisture content in cob.

Potassium plays an important role in the synthesis of amino acid which constitutes building block of protein.

The whole structure of proteins and protein activity needs high concentrations of $\mathrm{K}^{+}$in the cytosol for optimum plant functions.

It might have resulted in higher protein content. The results are in accordance with those reported by Haji et al., (2009) and Brar et al., (2011). 

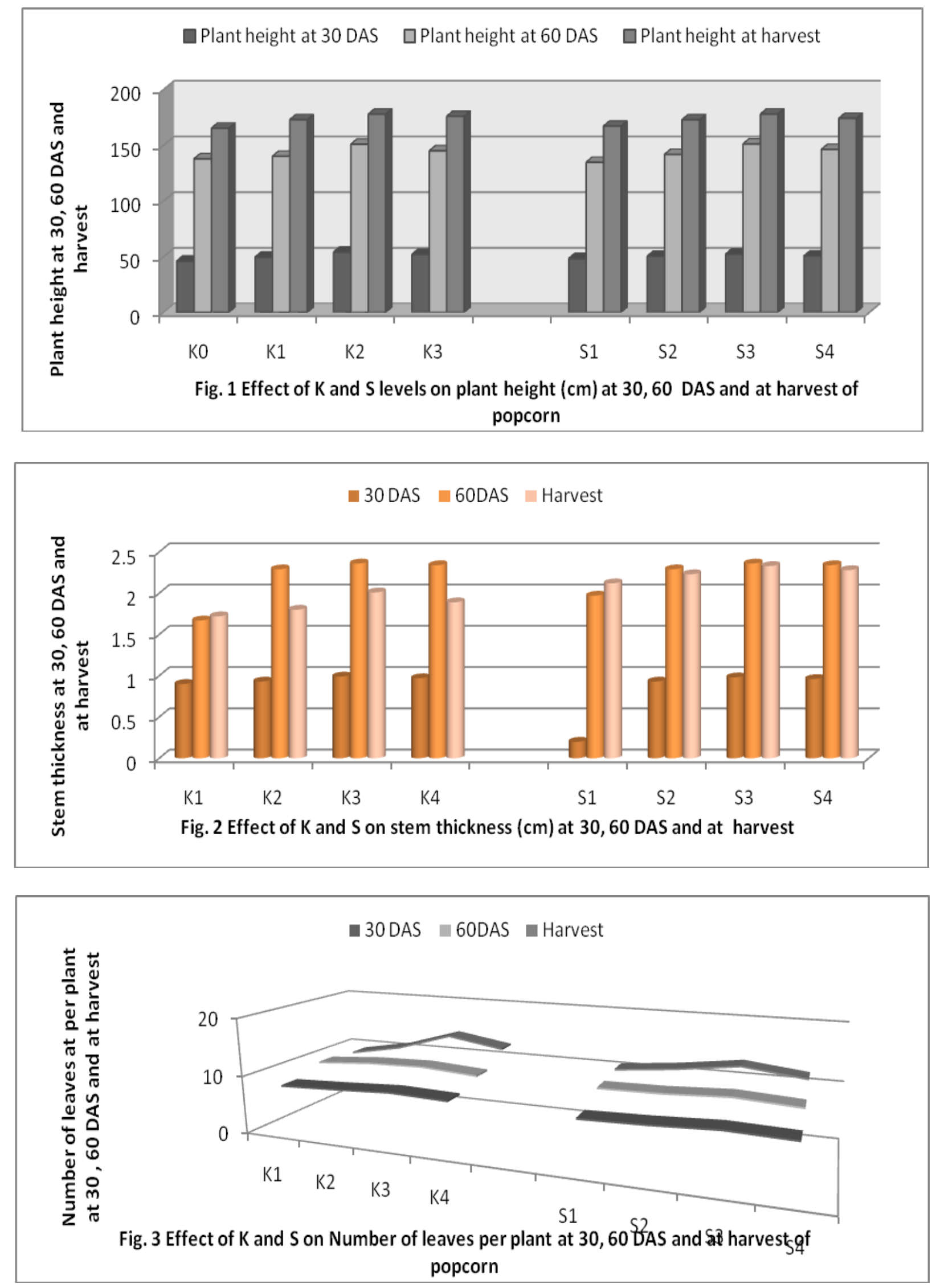
Table.1 Effect of potassium and sulphur on growth and quality parameters of popcorn

\begin{tabular}{|c|c|c|c|c|c|c|c|c|c|c|c|c|c|c|}
\hline \multirow[t]{2}{*}{$\begin{array}{l}\text { Treatme } \\
\text { nts }\end{array}$} & \multicolumn{3}{|c|}{ Plant height (cm) } & \multicolumn{3}{|c|}{ Stem thickness (cm) } & \multicolumn{3}{|c|}{$\begin{array}{c}\text { Number of leaves per } \\
\text { plant }\end{array}$} & \multirow{2}{*}{$\begin{array}{c}\text { Days to } \\
50 \% \\
\text { silking }\end{array}$} & \multirow{2}{*}{$\begin{array}{c}\text { Days to } \\
50 \% \\
\text { tasseling }\end{array}$} & \multirow{2}{*}{$\begin{array}{l}\text { Leaf } \\
\text { stem } \\
\text { ratio }\end{array}$} & \multicolumn{2}{|c|}{ Quality parameters } \\
\hline & $\begin{array}{l}\text { 30DA } \\
\text { S }\end{array}$ & 60DAS & Harvest & 30DAS & $\begin{array}{c}\text { 60D } \\
\text { AS }\end{array}$ & $\begin{array}{c}\text { Harve } \\
\text { st }\end{array}$ & $\begin{array}{l}\text { 30DA } \\
\text { S }\end{array}$ & $\begin{array}{l}\text { 60DA } \\
\mathrm{S}\end{array}$ & Harvest & & & & $\begin{array}{c}\text { Crude } \\
\text { protein } \\
\text { percent } \\
(\%)\end{array}$ & $\begin{array}{c}\text { Moisture } \\
\text { content } \\
(\%)\end{array}$ \\
\hline \multicolumn{15}{|c|}{ Potassium levels ( $\mathrm{kg} \mathrm{K}_{2} \mathrm{O} \mathrm{ha}^{-1}$ ) } \\
\hline $\mathrm{K}_{1}-0$ & 46.01 & 137.83 & 185.34 & 0.90 & 1.67 & 1.97 & 8.05 & 9.69 & 9.17 & 57.92 & 52.50 & 0.89 & 10.68 & 39.79 \\
\hline $\mathrm{K}_{3}-60$ & 54.08 & 150.92 & 197.91 & 0.99 & 2.03 & 2.36 & 8.97 & 10.70 & 14.00 & 51.83 & 47.92 & 0.98 & 12.07 & 34.62 \\
\hline $\mathrm{K}_{4}-90$ & 52.07 & 144.97 & 195.98 & 0.97 & 1.91 & 2.34 & 8.64 & 10.03 & 12.38 & 52.67 & 48.67 & 0.96 & 11.35 & 36.94 \\
\hline S.Em. \pm & 2.04 & 2.50 & 2.60 & 0.03 & 0.04 & 0.05 & 0.28 & 0.26 & 0.35 & 1.59 & 1.60 & 0.03 & 0.21 & 1.26 \\
\hline $\begin{array}{l}\text { C.D. } \\
(\mathrm{P}=0.05)\end{array}$ & NS & 7.23 & 7.50 & NS & 0.12 & 0.13 & NS & NS & 1.01 & NS & NS & NS & 0.62 & NS \\
\hline $\mathrm{S}_{3}-40$ & 52.29 & 151.13 & 197.96 & 0.98 & 2.01 & 2.33 & 8.93 & 10.67 & 12.89 & 52.58 & 48.21 & 0.97 & 11.80 & 35.78 \\
\hline$S_{4}-60$ & 50.68 & 146.25 & 194.18 & 0.96 & 1.89 & 2.28 & 8.61 & 10.08 & 11.70 & 53.08 & 49.08 & 0.95 & 11.46 & 36.65 \\
\hline S.Em. \pm & 2.04 & 2.50 & 2.60 & 0.03 & 0.04 & 0.05 & 0.28 & 0.26 & 0.35 & 1.59 & 1.60 & 0.03 & 0.21 & 1.26 \\
\hline $\begin{array}{l}\text { C.D. } \\
(P=0.05)\end{array}$ & NS & 7.23 & 7.50 & NS & 0.12 & 0.13 & NS & NS & 1.01 & NS & NS & NS & 0.62 & NS \\
\hline \multicolumn{15}{|c|}{ KxS Interaction } \\
\hline S.Em. \pm & 4.08 & 5.0 & 5.2 & 0.06 & 0.08 & 0.09 & 0.55 & 0.53 & 0.70 & 3.18 & 3.21 & 0.5 & 0.43 & 2.51 \\
\hline $\begin{array}{l}\text { C.D. } \\
(P=0.05)\end{array}$ & NS & NS & NS & NS & NS & NS & NS & NS & NS & NS & NS & NS & NS & NS \\
\hline C.V.\% & 14.02 & 6.07 & 4.66 & 11.06 & 7.51 & 7.06 & 11.21 & 8.95 & 10.41 & 10.19 & 11.17 & 9.75 & 6.60 & 11.70 \\
\hline
\end{tabular}




\section{Effect of sulphur}

Application of $40 \mathrm{~kg} \mathrm{~S} \mathrm{ha}{ }^{-1}\left(\mathrm{~S}_{3}\right)$ resulted significantly higher crude protein content of seed $(11.80 \%)$, which was found statistically at par with $60 \mathrm{~kg} \mathrm{~S}^{-1}\left(\mathrm{~S}_{4}\right)$ with the value of $11.46 \%$ (Table 1) and various levels of sulphur manifested their non- significant influence on moisture content in cob.

The probable result might be that sulphur plays an important role in synthesis of essential amino acids like cystiene, cystine, methionine and certain vitamins like Biotin, Thiamine, Vitamin $\mathrm{B}_{1}$ as well as formation of ferodoxin an iron-containing plant protein that acts as an electron carrier in the photosynthetic process and chlorophyll formation, which required for the production of protein (Zehler and Kreipe, 1981).

A shortage in the $S$ supply affects the utilization of the available nitrogen by crop (Likkineni and Abrol, 1994). Since, nitrogen and sulphur are required for the synthesis of proteins; the ratio of total $\mathrm{N}$ to total $\mathrm{S}$ in plant tissue has a direct bearing on protein synthesis. The findings close agreement with those obtained by Brunold and Suter, 1984, Jat et al., (2002), Sharma et al., (2004), Sheta et al., (2010) and Roshan and Nepalia (2013).

\section{Interaction effect}

The interaction effect of potassium and sulphur levels on crude protein content of seed was found non- significant (Table 1). The findings are in accordance with those of Jones and Wendt (1994) and Chaudhari (2012).

Based on the experimental results, it can be concluded that significantly improved growth parameters and higher crude protein content were obtained from rabi popcorn (cv. Amber) by fertilizing the crop with potassium $60 \mathrm{~kg}$
$\mathrm{K}_{2} \mathrm{O} \mathrm{ha}^{-1}\left(\mathrm{~K}_{3}\right)$ and sulphur up to $40 \mathrm{~kg} \mathrm{~S} \mathrm{ha}^{-1}$ $\left(\mathrm{S}_{3}\right)$ in medium black calcareous soils of South Saurashtra region of Gujarat.

\section{References}

Ahmed, F. Abid., M.M., Mahmood, T., Ali, M., Anwar, M.A. and Sandhu, N.A. 1992. Effect of potassium in different proportions with nitrogen and phosphorus on growth, yield and oil contents of sunflower (Helianthus annus L.). J. Agril. Res., 30:353-357.

Aslam, M., Shahid, M., Zamir, I., Afzal, I., and Yaseen, M. 2013. Morphological and physiological response of maize hybrids to potassium application under drought stress. J. Agril. Res., 51(4).

Bhatt, R.K.B. and Jain, N.K. 2012. Response of sweet corn (Zea mays (L.) Saccharata sturt) to sulphur and zinc fertilization. Res. Crops, 13(2):760-763.

Brar, M.S., Sing, B., Bansal, S.K. and Srinivasarao, C. 2011. Role of potassium nutrition in nitrogen use efficiency in cereals. International Potash Institute, 29:20-27.

Brar, M.S., Preeti, S., Amandeep Singh and Saandhu, S.S. 2012. Nitrogen Use Efficiency (NUE), Growth, Yield Parameters and Yield of Maize (Zea mays $L$.) as Affected by $\mathrm{K}$ application Res., 30 (March).

Brunold C. and Suter M. 1984. Regulation of sulphate assimilation by nitrogen nutrition in the duckweed (Lemna minor. L), Plant Physiology, 76: 579583.

Chaudhari, 2012. Effect of potassium and sulphur on growth, yield and quality of summer pearl millet. M.Sc. thesis Dept. of Agro.

Dechassa, C.S. Hunshal, S.M. Hiremath, J.S. Awaknavar, M.C. Wali, B.T. Nadagouda and Chandrashekar, C.P. 2013. Performance of maize (Zea mays 
L.) hybrids as influenced by different levels of nitrogen, phosphorus, potassium and sulphur application. Karnataka J. Agril. Sciences. 26(2): 194-199.

Haji,M. A.A., Bukhsh, A., Ahmad, R., Ishaque, M and Malik, A. U. 2009. Response of maize hybrids to varying potassium application in Pakistan. Pak. J. Agri. Sci., 46(3):179-184.

Jat, R.L., Sharma, O.P. and Chaudhari, A.C. 2002. Effect of nitrogen and sulphur on yield and quality of pearl millet (Pennisetum glaucum). Annals of Agril. Res., 23(2): 226-228.

Jones, R. B. and Wendt, J.W. 1994. Contribution of soil fertility research to improved maize production by smallholders in eastern and southern Africa. $4^{\text {th }}$ Eastern and southern Africa regional maize conference, pp: 2-14.

Kalpana, R. and Krishnarajan, J. 2002. Effect of dose and time of application on yield and quality of baby corn. Agril. Sciences. Digest, 22(1):59-60.

Likkineni, K.C. and Abrol, Y.P. 1994. Sulphur requirement of crop plants: Physiological Analysis. Fertilizer. News Letter, 39: 11-18.
Maurya, K.L. Sharma, H.P. Tripathi, H.P. and Sher Singh, 2004. Effect of fertility levels of nitrogen and sulphur on growth yield and quality of winter maize. Haryana J. of Agro, 20(1/2):8081.

Roshan, C.S.D. and Nepalia, V. 2013. Productivity and economics of quality protein maize (Zea mays) as influenced by nitrogen levels, its scheduling and sulphur application. Indian $J$. Agronomy, 58(3):340-343.

Sharma, H.R., Gupta, A.K., and Sharma S.K. 2004. Quality and nutrient uptake of arid kharif crops as affected by sulphur. Annals of Agril. Res., 25(4):633-635.

Sheta, B.T., Kalyanasundaram, N.K., Panchal, D.B., Patel, H.K. and Patel, J.C. 2010. Influence of nitrogen, potassium and sulphur levels on growth, yield and yield attributes of forage pearl millet [Pennisetum glaucum (L.) R. Br.]. Research on Crops, 11(2): 302-307.

Zehler, E. and Kreipe, H. 1981. Potassium sulphate and potassium chloride, their influence on yield and quality of cultivated crops. IPR research topics, No. 9.

\section{How to cite this article:}

Pamu Swetha, S.G. Savalia, Shalini Kumari and Dharmik Solanki. 2017. Growth and Quality Parameters of Popcorn (Zea Mays var. Everta) as Influenced by Application of Potassium and Sulphur Levels. Int.J.Curr.Microbiol.App.Sci. 6(8): 639-645. doi: https://doi.org/10.20546/ijcmas.2017.608.081 